Helena. Through the courtesy of M. le Commandant Henry Lachouque, the great French expert on Napoleon's life and the organizer of the permanent Napoleonic exhibitions on St. Helena and in the French Army Museum, hair taken from Emperor Napoleon I's head, probably on the day after his death, has been made available to us.

The hair sample thus obtained was sent to the Department of Forensie Medicine at the University of Glasgow, where it was examined using an activation analysis technique (Smith, 1959) as follows.

The hair sample was weighed $(1.72 \mathrm{mgm}$.) and sealed in a polythene container. It and a standard arsenic solution sealed in a silica ampoule were irradiated by thermal neutrons for one day at $10^{12}$ neutrons $/ \mathrm{cm} .{ }^{2} / \mathrm{sec}$. in a nuclear reactor at the Atomic Energy Research Establishment, Harwell. There. after the sample was returned and the arsenic extracted with added carrier arsenic by a modified Gutzeit technique. The activity from the hair sample was compared with that from the standard arsenic sample and the arsenic content of the hair was calculated.

The value found for the sample of hair was $10 \cdot 38$ parts per million. This is high by comparison with the normal mean arsenic content of about 0.8 p.p.m. Unfortunately, it was not possible to make any distribution studies as no further hair samples were available. It is impossible to tell from the value alone whether the arsenic was evenly distributed (as expected in continuous exposure) or located in one point (as would be the case in a single large exposure).

This investigation shows the great advantage of activation analysis when only very small quantities of sample are available.
BIBLIOGRAPHY

Antommarchi, F., Les derniers momens de Napolén (Paris, 1825). Arnott, A., An Account of the Last Illness, etc. (London, 1822). Beckmann, K., "Krankheiten der Leber", in Handbuch der inneren Medizin, 3, 2 (1953).

Bertrand, H.-G., Cahiers de Sainte-Hélène (Paris, 1949, 1951, 1959).

Boutron et al., Annales d'Hyg. pub. et Méd. leg., 25, 11 (1841).

Cabanès, Au chevet de l'Empereur (Paris, 1924).

Cabanès and Nass, Poisons et Sortilèges (Paris, 1903).

Douris, R., Toxicologie moderne (Paris, 1951).

Forshufvud, S., Le drame de Poison a Sainte-Hélene (Plon, Paris, 1961; in the press)

Forsyth, W., History of the Captivity, etc. (London, 1853).

Funck-Brentano, F., Le drame des poisons (Paris, 1920).

Gigon, A., "Krankheiten der Mundschleimhaut", in Handbuch der inneren Medizin, 3, 1 (1953).

Gonnard, Ph., Lettres du Comte et la Comtesse de Montholon, 1812 1821 (Paris, 1906).

Gourgaud, G., Journal de Sainte-Helene (Paris, 1947).

Gril, E., La Marquise de Brinvilliers Empoisonneuse (Paris, 1933).

Hansen, F., and Møller, K., Acta pharm., 5, 135 (1949).

Heffter, A., Deutsch. med. Wschr., 47, 853 (1921).

Kalima, T., Acta chir, scand., 72,1 (1932).

Kemble, J., Napoleon Immortal (London, 1959).

Kratter, J., Lehrbuch der gerichtlichen Medizin (Stuttgart, 1912).

Las Cases, E., Mémorial de Sainte-Helène (Paris, 1823).

Liebegott, G., Deutsch. med. Wschr., 74, 855 (1949).

McNally, W. J. Amer, Chem. Assoc., 39, 826 (1917).

Marchand, L., Mémoires de Marchand, 2 (Lachouque, Paris, 1955).

Mayers, M., Arch. Indust. Hyg., 9, 388 (1954).

Merkel, H., "Die Magenverätzungen", in Handbuch der spez. path. Anatomie $u$. Histologie (Henke and Lubarsch, Berlin, 1926).

Montholon, Ch., Histoire de la Captivité, ete. (Leipzig, 1846).

Munch-Pedersen, C. J., "Polyneuritis", in Nord. lärobok $i$ internaed, 5 (1958).

Nass, L., Les empoisonnements sous Louis XIV (Paris, 1898).

O'Meara, B., Napoleon in Exile (London, 1822).

Petri, E., "Path. Anatomie und Histologie der Vergiftungen", in Handbuch der spez. path. Anat. u. Hist. (Henke and Lubarseh, Berlin, 1930).

Saint-Denis, L., Souvenirs du Mameluck Ali sur l'Empereur Napoleon (Paris, 1926).

Smith, H., Anal. Chem., 31, 1361 (1959).

Watjen, J., Virchows Arch. path. Anat. u. Phys., 256, 85 (1925).

\title{
TEACHING MACHINES
}

Co many members were interested in the sym$S$ posium on "Teaching Machines" in Section $J$ (Psychology) at the British Association meeting at Norwich on September 4 that the 'house-full' notice had to be used. Introducing the subject, the chairman, Prof. H. Kay, pointed out the theoretical and practical implications of teaching machines. It is likely that their use in research will contribute considerably to our understanding of learning processes. Psychologists recognize that hitherto they have carried out extensive experiments on animal behaviour but have neglected the study of human learning. Here is a definite opportunity to examine in ideally controlled conditions the variables which are influencing learning. On the practical side there is not only a desperate national need for teachers, particularly in science subjects, but also an increasing problem of how to impart technological information on a worldwide scale. The urgent need is for new forms of communication; teaching machines represent one such form.

Dr. J. Annett, of the Department of Psychology, University of Sheffield, outlined the main requirements for a teaching machine. It is a device not only for imparting information but also for sensing that this information has been received and understood. It is a two-way communication channel designed at every stage to check the progress of the student and, ideally, to modify its instructions on the basis of the students' responses. This may be achieved by several methods. Perhaps the simplest is the small step or linear-type programming developed by Prof. Skinner at Harvard, where a series of statements and questions are built up and are repeatedly modified on the basis of the actual success of students in mastering them. Eventually a sequence is established so that when this programme is presented to other students nearly all the problems of subject-matter presentation have been anticipated. Such a programme is time-consuming to prepare, is lengthy in so far as there are many items with short steps between them, but is efficient and requires little use of 'gadgets' for presentation.

An alternative system is known as intrinsic programming. Here there is a main line of communication, and provided a student can respond correctly he can proceed smoothly along this route. But if he makes a mistake he is directed to a branch line, where further explanations are given before returning him to the main sequence. Dr. Annett explained that in the type of machine constructed at the Department at Sheffield this system had been achieved by a sequence of ' $A$ ' frames and ' $B$ ' frames. If any one of the ' $A$ ' frames is misunderstood, a ' $B$ ' frame is selected and the point is explained in greater detail. This type of machine is flexible enough to cope with students differing considerably in intellectual ability. A machine might operate on a 
'constructed response mode' where the student first makes his own answer and compares it with the answer which is then supplied by the machine, or, on an alternative procedure, where the machine first supplies a multi-choice solution and the student has to select the correct response. The advantages of these procedures are being investigated.

Mr. Leslie Reid, lecturer in psychology in the University of Aberdeen, discussed and actually produced the simpler forms of teaching machines which he has developed and is using at present in his research work in Scottish schools. His programmes have followed Skinner's principles with an accent on eliminating frustration and difficulties. From this point of view, teaching machines preserve the teacher-pupil relationship by ensuring that pupils are consistently rewarded, and not punished, for their responses. This is achieved primarily by the ordering of items in a suitable sequence, such that the transition from ignorance to knowledge is not a bumpy and apparently unmapped journey, but a smooth and logical progression in which a pupil can be expected to achieve success. Mr. Reid explained how a pupil working through a programme achieves insight through a gradual understanding of his subject; by contrast, that insight which a pupil achieves by a sudden flash of comprehension-the so-called 'eureka' phenomenon-is mainly a product of bad teaching.

Mr. Gordon Pask, of System Research, explained the principles of an adaptive teaching machine. Unlike a programmed machine the adaptive device itself 'learns' about the student's behaviour and modifies the training routine to suit each individual throughout the learning process. In teaching a manual skill the designer has to select certain parameters. These refer both (1) to the students' behaviour, such as the response latency, and (2) to the instructor's behaviour, such as the amount of 'cue' information with each category of problem. It will be observed that the parameters in (1) define measures of the student's behaviour which an instructor might make, and those in (2) consider the ways in which the instructor might manipulate a training routine. Thus the designer is constructing a computing device which measures the performance and then by an adaptive servo-mechanism adjust the parameters of (2) in order to increase to a maximum the performance measure. Well-designed machines adopt a competitive strategy when the student is doing well and a co-operative strategy when he is making no improvement. Mr. Pask went on to describe how adaptive teaching machines might be used for group or classroom instruction. Here students are carrying out exercises in scientific inference and act either as a problem poser or a problem solver. The student coming quickest to the right conclusion using the minimum of evidence is most successful. A miniature economy is imposed on the group, and the machine controls the group's behaviour by modifying the parameters of the game. The most useful parameters seem to be 'cost' of communication, 'cost' of evidence, 'gain' for successful solution, and a bias on the process of role assignment.

Mr. K. Austwick, of the University of Sheffield, presented "An Educational Viewpoint" on the subject. Mr. Austwick has conducted preliminary experiments at schools on the teaching of mathematics with a simple linear programmed procedure. Preliminary results are encouraging and suggest that work learned by this method is well retained over a period of time. Programming of school and university courses is now under way. If such procedures were widely adopted they could lead to modifications in school design since they do not require the formal arrangement of a classroom. The possibilities of such machines to handicapped children, isolated children, personnel in the Services, and adults keeping up to date in a subject were brought out. On the other hand, the machines could not take over the 'human' role of the teacher, though they might give the teacher more time and opportunity to show his humanity.

The discussion was brisk enough and ranged from the university teacher anxious to discover how far machines could take over the part of tutor to a selfstyled 'plain local family doctor' who knew they could not. These are early days for the teachingmachine movement, but it was apparent that we have here an educational development which is already arousing considerable interest and some oppositionboth happy indexes. In a remarkably short time this type of instruction has now used 'hardware' ranging from simple pencil and paper booklets to electronic gadgets controlled by a full-scale computor. Systems are already being produced for public sale by both the publisher and the electronics industry. It is clear that the results of research are needed to give some guidance to this diversity, but research efforts in Britain are, as usual, on a small scale. To the academic psychologist this subject represents a further development in the field of communication systems, and it now offers another opportunity for studying how man can most efficiently receive and store information. But the pace and detachment of academic research are confronted by the urgency of the demand for instruction. The need in Britain for scientific and technical teaching is obvious enough, but is trivial in comparison with other areas of the world. Part of the impotus behind automated teaching is that universally, in so many subjects, there is so much demand for knowledge. There is every indication that this demand will continue to increase, and that it cannot be fulfilled by conventional methods.

\section{BREATHING}

$\mathrm{U}$ NDER the chairmanship of the Section's president, Sir Bryan Matthews, a symposium on "Breathing (External Respiration)" was held on September 4 by Section I (Physiology and Biochemistry) during the recent British Association meeting in Norwich. Four papers were presented, covering varied topies connected with respiratory physiology. Two of these had a clinical bias, and concerned the distribution of ventilation and flow of blood in the lungs, and the effects of oxygen on breathlessness. The other two demonstrated the application of respiratory physiology to aviation, one concerning the design of an aircraft breathing system, and the other describing the results of research into the effects of positive acceleration on the mechanics of respiration. 